\title{
Natural Vertical Transmission of Zika Virus in Larval Aedes aegypti Populations, Morelos, Mexico
}

\author{
Mónica Izquierdo-Suzán, Selene Zárate, Jesús Torres-Flores, \\ Fabián Correa-Morales, Cassandra González-Acosta, Edgar E. Sevilla-Reyes, \\ Rosalia Lira, Sofía L. Alcaraz-Estrada, Martha Yocupicio-Monroy
}

\begin{abstract}
We characterized natural vertical transmission of Zika virus in pools of Aedes aegypti larvae hatched from eggs collected in Jojutla, Morelos, Mexico. Of the 151 pools analyzed, 17 tested positive for Zika virus RNA; infectious Zika virus was successfully isolated from 1 of the larvae pools $(31 \mathrm{~N})$ in C6/36 cells. Real-time quantitative PCR and indirect immunofluorescence assays confirmed the identity of the isolate, named Zika virus isolate $31 \mathrm{~N}$; plaque assays in Vero cells demonstrated the isolate's infectivity in a mammalian cell line. We obtained the complete genome of Zika virus isolate $31 \mathrm{~N}$ by next-generation sequencing and identified 3 single-nucleotide variants specific to Zika virus isolate $31 \mathrm{~N}$ using the meta-CATS tool. These results demonstrate the occurrence of natural vertical transmission of Zika virus in wild $A e$. aegypti mosquitoes and suggest that this transmission mode could aid in the spread and maintenance of Zika virus in nature.
\end{abstract}

Z ika virus is an enveloped, positive-sense, singlestranded sRNA, arthropod-borne virus (arbovirus) that is classified in the genus Flavivirus, family Flaviviridae. Zika virus is closely related to other viruses of medical importance, such as dengue, West Nile, and yellow fever viruses (1). Zika virus was discovered in Uganda in 1947, but it has attracted the attention of specialists in the past few years because of its rapid spread through the Pacific and into the Americas in 2015, as well as the severe neurologic manifestations associated with Zika virus

Author affiliations: Universidad Autónoma de la Ciudad de Mexico, Mexico City, Mexico (M. Izquierdo-Suzán, S. Zárate,

M. Yocupicio-Monroy); Instituto Politécnico Nacional, Mexico City

(J. Torres-Flores); Centro Nacional de Programas Preventivos y

Control de Enfermedades, Mexico City (F. Correa-Morales,

C. González-Acosta); Instituto Nacional de Enfermedades

Respiratorias, Mexico City (E.E. Sevilla-Reyes); Instituto

Mexicano del Seguro Social, Mexico City (R. Lira); Instituto de

Seguridad y Servicios Sociales de los Trabajadores del Estado,

Mexico City (S.L. Alcaraz-Estrada)

DOI: https://doi.org/10.3201/eid2508.181533 infections, such as neonatal microcephaly and GuillainBarré syndrome (2).

Several studies carried out under laboratory conditions have demonstrated that Zika virus can infect many different Aedes mosquito species (3); still, the key species for the transmission of Zika virus to humans are Ae. aegypti and Ae. albopictus (4-6). In this study, we focused on the species Ae aegypti, which has an urban behavior and is usually in close contact with humans (7). To date, 2 different mechanisms by which Ae. aegypti mosquitoes can become infected with flaviviruses have been described: horizontal transmission and vertical transmission (8).

Horizontal transmission is considered the most common mode of transmission of arboviruses between mosquitoes and their vertebrate hosts and is responsible for the maintenance of arboviruses in nature, particularly during disease outbreaks. In contrast, the environmental maintenance of dengue virus (DENV) during interepidemic periods is thought to be caused by vertical transmission of the virus from the infected adult mosquitoes to their offspring for $\geq 7$ successive generations (9-11). Both mechanisms together are thought to be essential for the survival of viral pathogens in their habitats, preventing their extinction during harsh environmental conditions or in populations in which the presence of susceptible mammal hosts is low.

Vertical transmission of Zika virus in Ae. aegypti mosquitoes has been evaluated under laboratory conditions by searching for the presence of Zika virus RNA in several organs from the offspring of infected mosquitoes, demonstrating the presence of viral RNA in the guts and salivary glands of the offspring (12). Additional studies have also demonstrated the presence of infectious Zika virus in the offspring of artificially infected Ae. aegypti and Ae. albopictus mosquitoes, suggesting that vertical transmission can occur in laboratory-bred mosquitoes (13). However, evidence is insufficient to confirm that vertical transmission is a principal maintenance mechanism for Zika virus in wild Aedes mosquitoes. 
In this study, we sought to demonstrate natural vertical transmission in Ae. aegypti mosquitoes by detecting viral RNA and isolating infectious Zika virus from larvae hatched from field-collected eggs. We also assessed the infectivity of the isolate in a mammalian cell line and obtained the complete genome of the virus by next-generation sequencing (NGS).

\section{Materials and Methods}

\section{Study Site}

We collected mosquito egg samples in the municipality of Jojutla, located in the southern region of the state of Morelos, Mexico $\left(18^{\circ} 36^{\prime} \mathrm{N}, 99^{\circ} 10^{\prime} \mathrm{W}\right)$. Arboviral infections are common in this municipality, which is usually hot and dry during October-April and warm and humid during MaySeptember. During 2016, the incidence of Zika virus infections increased in Morelos; 269 cases were reported by the end of the year, of which 69 cases were from Jojutla. The reported cases in Jojutla were recorded as follows: 1 in August, 17 in September, 20 in October, 25 in November, and 6 in December (14).

\section{Egg Collection and Hatching}

We collected Ae. aegypti eggs in collaboration with the National Center of Preventive Programs and Disease Control (CENAPRECE), following regulations for entomological surveillance with ovitraps (NOM-032-SSA2-2014). In 2016, 180 ovitraps were placed and maintained throughout the year in different locations in Jojutla (Figure 1). We determined the locations of the ovitraps on the basis of the incidence of human arbovirus infections. We collected the eggs using filter paper, which we then air dried for 2 days and stored in paper bags for further use.

We placed the egg papers in water containers and incubated them at $37^{\circ} \mathrm{C}$ for $1 \mathrm{wk}$ under 24 -h light/dark cycles. After the incubation period, we collected larvae in stages 2-3 and separated them into pools of 20-30 larvae. We macerated each of the pools in viral transport media $(5 \%$ BSA, $100 \mathrm{U} / \mathrm{mL}$ penicillin, $100 \mu \mathrm{g} / \mathrm{mL}$ streptomycin, 2.5 $\mu \mathrm{g} / \mathrm{mL}$ fungizone, and $\mathrm{NaHCO}_{3}$ in Hank's solution) using a pestle mixer (Thomas Scientific, https://www.thomassci. com) and stored pools at $-80^{\circ} \mathrm{C}$ for further analysis.

\section{Detection of Zika Virus in Larvae of Aedes aegypti}

We incubated the macerated larvae pools with Trizol (Invitrogen, https://www.thermofisher.com) for $10 \mathrm{~min}$, extracted total RNA from the lysates using Zymo-Spin RNA extraction columns (Zymo Research, https://www.zymoresearch.com), and quantified the RNA with a Nano Drop 2000 (Thermo Scientific, https://www.thermofisher.com). We detected the presence of Zika virus RNA by quantitative reverse transcription PCR (qRT-PCR) using the TaqMan system (https://www.thermofisher.com) with primers

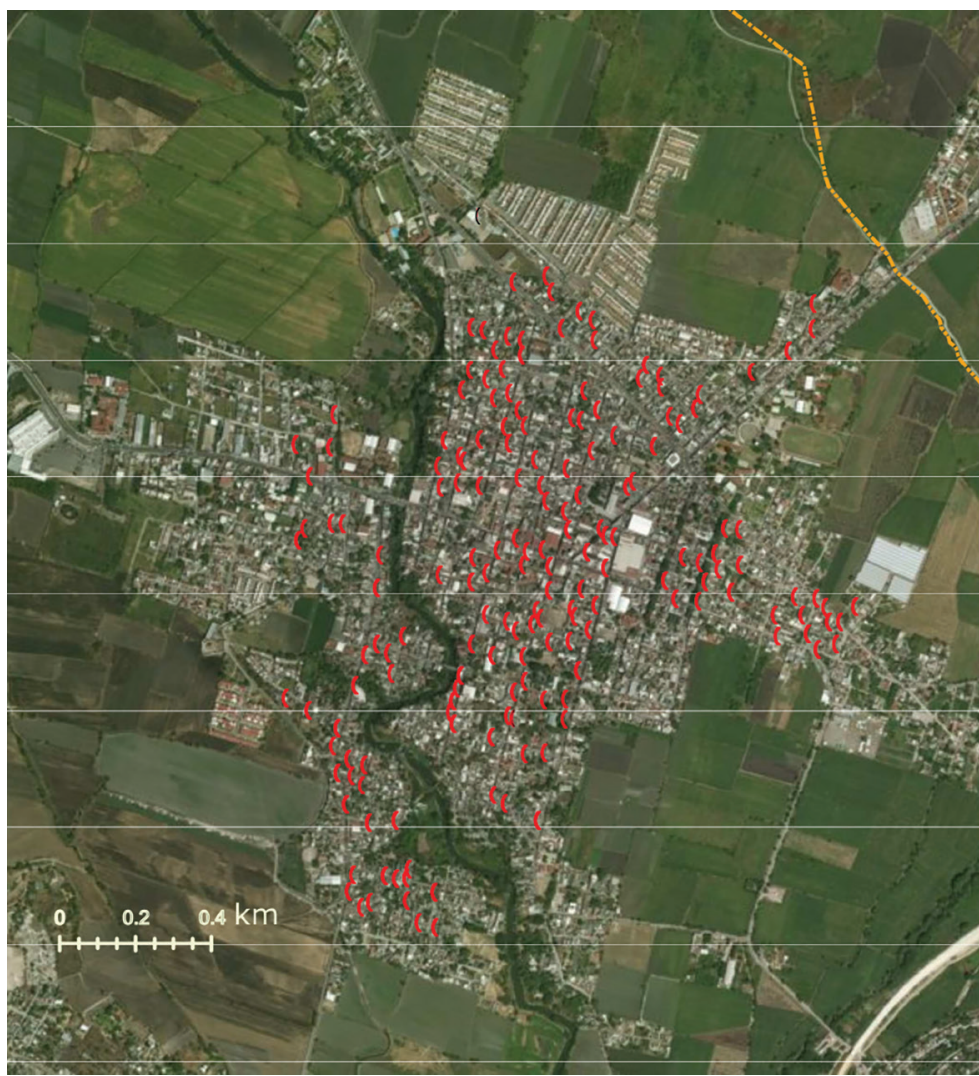

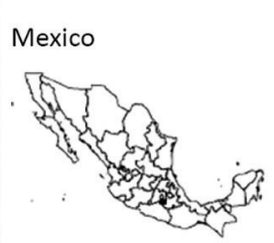

Morelos

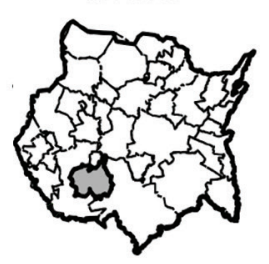

Figure 1. Location of ovitraps in the municipality of Jojutla, Morelos, Mexico (red). The ovitraps were set according to the guidelines of the Vector Transmitted Diseases Program of the National Center of Preventive Programs and Disease Control (CENAPRECE; http://www.cenaprece.salud. gob.mx/programas/interior/ portada_vectores.html). Insets show location of Morelos in Mexico (top) and Jojutla in Morelos (bottom). 
Zikv 1086 Fw 5'-CCGCTGCCCAACACAAG-3' and Zikv 1162c Rv 5'-CCACTAACGTTCTTTTGCAGACAT-3'; and probe Zikv 1107-FAM probe 5'-AGCCTACCTTGACAAGCAGTCAGACACTCAA-3', as previously described by Lanciotti et al. (15). We calculated the minimum infection rate (MIR) of the larvae pools by dividing the number of positive larvae pools by the total number of larvae tested and multiplying by 1,000 .

\section{Viral Isolation and Identification}

We selected the larvae pools that tested positive for Zika virus RNA and displayed the lowest quantitation cycle (Cq) values (range 22.3-33.4) for viral isolation. In brief, we diluted macerated larvae pools in maintenance medium (EMEM medium with $1 \%$ FBS, $100 \mathrm{U} / \mathrm{mL}$ penicillin, and $100 \mu \mathrm{g} / \mathrm{mL}$ streptomycin) and filtered them through 0.22 $\mu \mathrm{m}$ membranes (Millex, http://www.emdmillipore.com). Twenty-four hours before infection, we seeded C6/36 cells in 24-well plates at $80 \%$ of confluence in growth medium (EMEM medium supplemented with 10\% FBS, $100 \mathrm{U} / \mathrm{mL}$ penicillin, and $100 \mu \mathrm{g} / \mathrm{mL}$ streptomycin) and incubated them at $28^{\circ} \mathrm{C}$ in a $5 \% \mathrm{CO}_{2}$ atmosphere. Cells were adsorbed with the clarified larvae macerates for $2 \mathrm{~h}$ at $28^{\circ} \mathrm{C}$. After the incubation period, we added fresh maintenance medium to the cells and left the infection to proceed for $7 \mathrm{~d}$ at $28^{\circ} \mathrm{C}$ and a $5 \% \mathrm{CO}_{2}$ atmosphere until a cytopathic effect was observable. We tested the supernatants of the infected cells for the presence of Zika virus RNA by qRT-PCR, as described earlier in this section. We performed 4 passages of each isolate in $\mathrm{C} 6 / 36$ cells to increase viral titers for NGS.

\section{Indirect Immunofluorescence Assay}

For the indirect immunofluorescence assays, we grew Vero cells over glass coverslips and then infected them with the Zika virus isolate. At 48 hours postinfection, we fixed cells with $4 \%$ paraformaldehyde and then incubated them with ice-cold methanol for $10 \mathrm{~min}$. We blocked the cells using $10 \%$ FBS in phosphate-buffered saline (PBS) for $1 \mathrm{~h}$ and then incubated them overnight at $4^{\circ} \mathrm{C}$ with a 1:500 dilution of the monoclonal antibody 4G2. After the incubation period, we washed the cells twice with PBS and then incubated them with an Alexa Fluor 488-conjugated goat antimouse IgG antibody (Jackson Immunoresearch, https://www.jacksonimmuno.com) for $1 \mathrm{~h}$. We washed the cells twice with PBS and then mounted them with VECTASHIELD medium with DAPI (Vector Laboratories, https://vectorlabs.com) for confocal microscopy (Nikon, https://www.nikon.com).

\section{Plaque Assays}

For the plaque assays, we seeded Vero cells in 24-well plates until they reached a confluence of $80 \%$. We used 10 -fold serial dilutions of the Zika virus isolate to infect the cell monolayers and left them to adsorb for $1 \mathrm{~h}$. After the adsorption period, we removed the virus and overlaid cell monolayers with $1 \mathrm{~mL}$ of DMEM (Invitrogen) supplemented with $2 \%$ carboxymethyl-cellulose (Sigma-Aldrich, https://www.sigmaaldrich.com), 2\% FBS, $100 \mathrm{U} / \mathrm{mL}$ penicillin, $100 \mu \mathrm{g} / \mathrm{mL}$ streptomycin, and $2 \mathrm{mM}$ L-glutamine (Gibco, https://www.thermofisher.com) and incubated at $37^{\circ} \mathrm{C}$ for $4 \mathrm{~d}$. We fixed the cells with $4 \%$ paraformaldehyde in PBS and counterstained them with crystal violet-formaldehyde (Sigma-Aldrich).

\section{Full Genome Sequencing and Assembly}

For the complete genome sequencing of the Zika virus isolate, we depleted $200 \mathrm{ng}$ of total RNA extracted from the supernatants of infected Vero cell monolayers of rRNA using the NEBNext rRNA Depletion Kit (human/mouse/rat) following the manufacturer's instructions (New England Biolabs, https://www.neb.com). We constructed RNaseq Illumina shotgun libraries at the Unidad Universitaria de Secuenciación Masiva y Bioinformática-Instituto de Biotecnología and sequenced them using paired-end sequencing with a MySeq system (Illumina, https:/www.illumina. com). We assessed the quality of reads using FASTQC (http://www.bioinformatics.babraham.ac.uk/projects/ fastqc); low-quality positions and reads were eliminated using in-house scripts. We assembled the valid reads without reference using the program Trinity 2.8 (16) and evaluated the assembly using Qualimap (17). Finally, we verified the identity of the contig using blastn (http://blast.ncbi. nlm.nih.gov/Blast.cgi).

\section{Phylogenetic Reconstruction}

To determine the phylogenetic relatedness of the Zika virus isolate, we retrieved relevant $\mathrm{Zika}$ virus open reading frame (ORF) RNA sequences from the Virus Pathogen Resource (ViPR) database (18) (http://www.viprbrc.org). We removed identical sequences and those with undetermined bases from alignment. We applied near-identity clustering (0.999) to the remaining sequences in Cd-hit-test (19) and used 98 sequences for phylogenetic inference by maximum likelihood in RAxML (20) under a general time-reversible plus gamma substitution model. We reconstructed the tree with 200 bootstrap replicas. We normalized branch lengths and condensed nodes with bootstrap values $<50 \%$ to emphasize tree topology.

\section{Variant Analysis}

To determine the presence of variants in the larva-derived sequence, we used the alignment to identify positions that had mutations unique to our sequence or that were primarily shared with other mosquito-derived sequences and that were absent or rare in the human-derived genomes. To this end, we examined the alignment 
with the tool meta-CATS (21), which performs a $\chi^{2}$ test to find positions with different polymorphism distribution between groups.

\section{Results}

\section{Zika Virus Isolation and Identification in Ae. aegypti Larvae}

During the study period, we analyzed 151 larvae pools by qRT-PCR in search of Zika virus RNA. Only 17 (10.8\%) of the pools tested positive: $9(5.7 \%)$ from the larvae raised from the eggs collected in June and $8(5.1 \%)$ from larvae raised from the eggs collected in November. To determine the proportion of infected larvae in the population, we calculated MIRs for the 2 collection periods (June and November 2016) and found an increase in the MIR observed from the larvae raised from the eggs collected in June (2.5) to the MIR from the eggs collected in November (6.9) (Table 1).

To confirm the presence of infectious Zika virus in the larvae pools, we used 11 of the 17 pools that tested positive for Zika virus RNA that displayed the lowest $\mathrm{Cq}$ values to attempt viral isolation. We were able to isolate infectious Zika virus from only 1 of the larvae pools $(31 \mathrm{~N})$, as determined by the presence of cytopathic effect in C6/36 cells characterized by monolayer detachment (Figure 2, panel A) and the detection of Zika virus RNA in culture supernatants by qRT-PCR with a Cq value of 23.73 .

The ability of the $31 \mathrm{~N}$ isolate to infect a mammalian cell line was confirmed by the appearance of the characteristic cytopathic effect of Zika virus in infected Vero cell cultures, characterized by cell rounding and detachment (Figure 2, panel A). Moreover, immunofluorescent detection of the viral envelope (E) protein using the monoclonal antibody 4G2 revealed perinuclear staining (Figure 2, panel B). The plaque assays carried out in Vero cells revealed that the $31 \mathrm{~N}$ isolate has the ability to produce lytic plaques; thus, this isolate can be considered cytopathic in mammalian cell culture (Figure 2, panel C).

\section{Complete Genome Sequencing of Zika Virus Isolate 31N}

We isolated viral RNA from the supernatant of Vero cells infected with the fourth passage of Zika virus isolate $31 \mathrm{~N}$ and processed it by RNA sequencing by the NGS MiSeq Illumina protocol. Around $40 \%$ of the total reads $(6,535,816)$ were assembled in a single contig of 10,795 nt in length, with a mean depth of 42,000 reads. BLAST results of the assembled contig revealed that the strain ZIKV/Aedes.sp/MEX/MEX_I-7/2016, which belongs to a Zika virus isolated from Aedes mosquitoes obtained in the state of Chiapas, Mexico, had the highest identity $(98.8 \%)$ with our isolate.
Table 1. MIR for Zika virus in Aedes aegypti larvae, Jojutla, Morelos, Mexico, June and November 2016*

\begin{tabular}{lccc}
\hline Collection date & $\begin{array}{c}\text { Positive pools/ } \\
\text { analyzed pools }\end{array}$ & $\begin{array}{c}\text { Specimens } \\
\text { analyzed }\end{array}$ & MIR \\
\hline June & $9 / 105$ & 3150 & 2.8 \\
November & $8 / 46$ & 1150 & 6.9 \\
\hline${ }^{*}$ MIR, minimum infection rate. & & \\
\hline
\end{tabular}

\section{Variant Analysis}

We identified single-nucleotide variants (SNVs) in the Zika virus isolate $31 \mathrm{~N}$ genome by aligning the sequence with other mosquito- and human-derived sequences obtained from the ViPR database and running the metaCATS analytic tool, as described in the Materials and Methods section. To carry out this analysis, we grouped the sequences by the host of origin. We identified SNVs in positions 3176,3286 , and 5636 that were unique to the larva genome. On the other hand, the SNVs in positions 2071 and 3333 were found in human-derived sequences but were not present in other mosquito genomes. The SNV in position 2071 was shared only with a sequence from French Polynesia, likely an example of parallel evolution, whereas the polymorphism in position 3333 was common with 2 sequences from Mexico and may correspond to a local variant. Finally, we found 8 SNVs that were also present in other human and mosquito sequences but were more common in mosquitoes. Only $1 \mathrm{SNV}$ was found in the $\mathrm{E}$ gene, whereas the rest were found in nonstructural (NS) genes: 5 in NS2A, 4 in NS3, 2 in NS5, and 1 in NS1 (Table 2).

\section{Phylogenetic Reconstruction of Zika Virus}

To characterize the evolutionary relationship between the $31 \mathrm{~N}$ isolate and other Zika virus genomes that have been previously reported, we performed a phylogenetic analysis. The phylogenetic reconstruction of the complete genomes of 98 Zika virus sequences, including the $31 \mathrm{~N}$ isolate, revealed that the $31 \mathrm{~N}$ isolate belongs to the AsianAmerican lineage of Zika virus and clusters together with other sequences of human and mosquito origin from Mexico (Figure 3).

\section{Discussion}

Natural vertical transmission of mosquito-carried viruses has been proposed as one of the main ecologic processes involved in the maintenance of these viruses in susceptible mosquito populations, particularly during interepidemic periods and harsh climate conditions when horizontal transmission becomes difficult $(11,22)$. In Mexico, most of the studies regarding natural vertical transmission of arboviruses in mosquitoes have been carried out using DENV as a study model (23-25), so the diversity of viruses that can be transmitted from infected adult mosquitoes to their offspring still needs to be characterized. 
A

\section{C6/36}

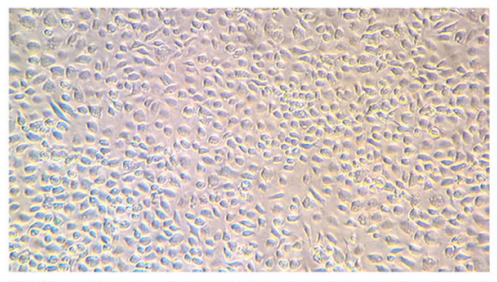

Control

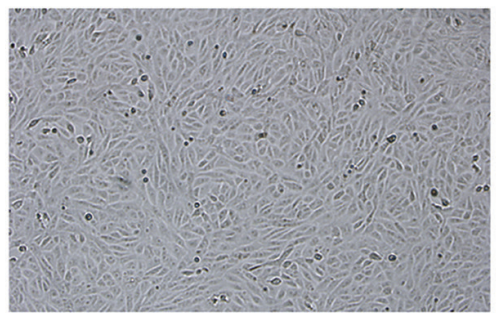

Zika virus isolate $31 \mathrm{~N}$
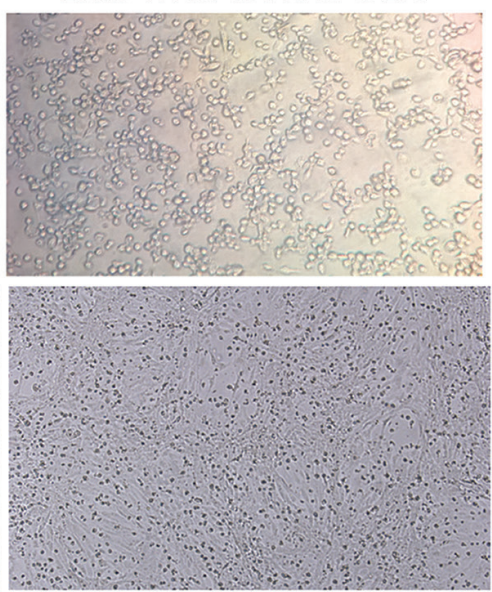

B

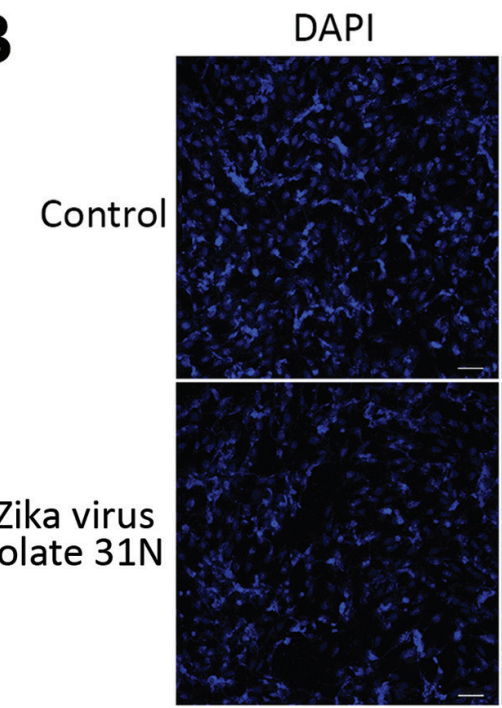

$10^{-1}$

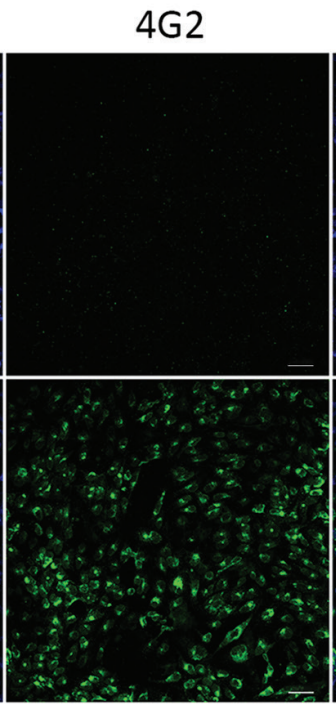

$10^{-2}$

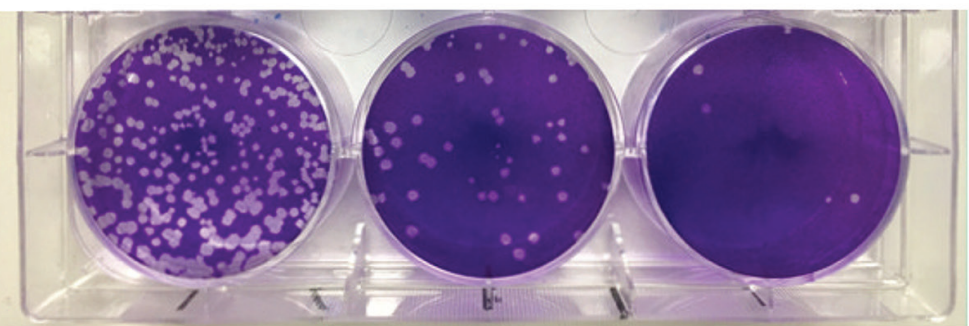

\section{C}

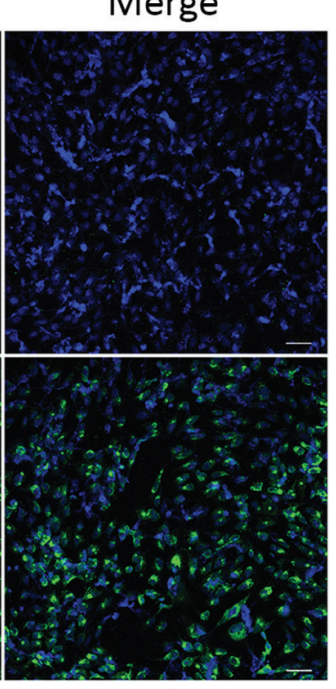

$10^{-3}$
Figure 2. Phenotypic analysis of Zika virus isolate $31 \mathrm{~N}$ from an Aedes aegypti larval pool, Jojutla, Morelos, Mexico. A) Cytopathic effect of the Zika virus isolate $31 \mathrm{~N}$ in C6/36 and Vero cells. The left panel shows mock infected cells. Original magnification $\times 20$. B) Infected Vero cells with Zika virus isolate $31 \mathrm{~N}$ at a multiplicity of infection of 0.1 and mock infected cells. Nuclei are stained in blue (DAPI), and the envelope protein is stained in green (4G2). Original magnification $\times 20$.

C) Plaque assay of Zika virus isolate $31 \mathrm{~N}$ in Vero cells. Serial decimal dilutions of Zika virus isolate $31 \mathrm{~N}$ are depicted.
Only a few studies have addressed the natural vertical transmission of Zika virus in wild mosquito populations; most of these have been carried out in Brazil, where Zika virus RNA has been detected in male Ae. aegypti mosquitoes and in adult Ae. albopictus mosquitoes raised from field-collected eggs $(26,27)$.

In this study, we demonstrated the occurrence of natural vertical transmission of Zika virus in wild mosquito populations from the municipality of Jojutla in the state of Morelos, Mexico. The RNA of Zika virus was detected in
17 larvae pools; the rates of vertical transmission of Zika virus in the wild Ae. aegypti populations were estimated by calculating the MIR. In Morelos, the rainy season begins in late May and extends through the end of September, after which both the precipitation and the mosquito populations start to decrease. Thus, the higher MIR (6.95) calculated from the larvae hatched from the eggs collected in November 2016, in contrast to the MIR from the larvae hatched from the eggs collected in June (2.6), might be correlated with the increased number of human Zika virus cases that 
Table 2. Residue diversity between Zika virus isolate $31 \mathrm{~N}$ from an Aedes aegypti larval pool and human- and mosquito-derived genomes, Jojutla, Morelos, Mexico*

\begin{tabular}{|c|c|c|c|c|c|c|}
\hline \multirow[b]{2}{*}{ Position } & \multirow{2}{*}{$\begin{array}{l}\text { Genome } \\
\text { region }\end{array}$} & \multicolumn{2}{|c|}{ Human-derived sequences } & \multicolumn{2}{|c|}{ Mosquito-derived sequence } & \multirow[b]{2}{*}{$p$ value } \\
\hline & & SNVs, \% & Origin of minority variant & SNVs, \% & Origin of minority variant & \\
\hline 1008 & $E$ & $\mathrm{~T} \rightarrow \mathrm{C}, 3.65$ & $\begin{array}{l}\text { Mexico, United States, } \\
\text { Thailand }\end{array}$ & $\mathrm{T} \rightarrow \mathrm{C}, 17.64$ & $31 \mathrm{~N}$, Mexico & 0.000253 \\
\hline $2071 †$ & NS1 & $\mathrm{C} \rightarrow \mathrm{T}, 0.26$ & French Polynesia & $\mathrm{C} \rightarrow \mathrm{T}, 2.94$ & $31 \mathrm{~N}$ & 0.03 \\
\hline 2871 & NS2A & $\mathrm{T} \rightarrow \mathrm{C}, 4.43$ & Mexico, United States & $\mathrm{T} \rightarrow \mathrm{C}, 35.29$ & $31 \mathrm{~N}$, Mexico, United States & $<0.0001$ \\
\hline $3176 \ddagger$ & NS2A & CS & & $A \rightarrow C, 2.94$ & $31 \mathrm{~N}$ & 0.01022 \\
\hline $3286 \ddagger$ & NS2A & CS & & $A \rightarrow G, 2.94$ & $31 \mathrm{~N}$ & 0.01022 \\
\hline 3333† & NS2A & $A \rightarrow G, 0.52$ & Mexico & $A \rightarrow G, 2.94$ & $31 \mathrm{~N}$ & $>0.05$ \\
\hline 3788 & NS2A & $\mathrm{C} \rightarrow \mathrm{T}, 0.26$ & Brazil & $\mathrm{C} \rightarrow \mathrm{T}, 8.82$ & $31 \mathrm{~N}$, Mexico & $<0.0001$ \\
\hline 4500 & NS2A & $A \rightarrow G, 3.65$ & $\begin{array}{l}\text { Mexico, United States, } \\
\text { Philippines, South Korea }\end{array}$ & $A \rightarrow G, 17.64$ & $31 \mathrm{~N}$, Mexico & 0.003847 \\
\hline 4624 & NS3 & $\mathrm{G} \rightarrow \mathrm{A}, 3.39$ & United States, Mexico & $\mathrm{G} \rightarrow \mathrm{A}, 17.64$ & $31 \mathrm{~N}$, Mexico & 0.002194 \\
\hline 4980 & NS3 & $\mathrm{T} \rightarrow \mathrm{C}, 6.00$ & $\begin{array}{l}\text { Mexico, Puerto Rico, } \\
\text { Colombia, United States }\end{array}$ & $\mathrm{T} \rightarrow \mathrm{C}, 17.64$ & $31 \mathrm{~N}$, Mexico & 0.01 \\
\hline $5636 \ddagger$ & NS3 & CS & & $\mathrm{C} \rightarrow \mathrm{T}, 2.94$ & $31 \mathrm{~N}$ & 0.01022 \\
\hline 7200 & NS5 & $\begin{array}{l}\mathrm{T} \rightarrow \mathrm{A} 0.26 \\
\mathrm{~T} \rightarrow \mathrm{C}, 3.91 \S\end{array}$ & Mexico, USA, Suriname & $\mathrm{T} \rightarrow \mathrm{C}, 17.64$ & $31 \mathrm{~N}$, Mexico & 0.006182 \\
\hline 9139 & NS5 & $\mathrm{C} \rightarrow \mathrm{T}, 0.52$ & Mexico & $\mathrm{C} \rightarrow \mathrm{T}, 11.76$ & $31 \mathrm{~N}$, Mexico & $<0.0001$ \\
\hline
\end{tabular}

${ }^{*} \mathrm{CS}$, conserved site in human-derived sequences; SNV, single nucleotide variant.

†SNVs in human-derived sequences but not in other mosquito genomes.

$\ddagger S N V s$ unique to the larva genome.

$\S$ Two SNVs located in the same genome position.

were reported in Jojutla during November, whereas during June no human cases were reported. The absence of reported Zika virus human cases in June could be the result of asymptomatic cases, cases clinically misdiagnosed as dengue virus infections, or both.

The higher number of persons infected with Zika virus in Jojutla during November reflects an increase in the number of infected mosquitoes resulting from horizontal transmission of the virus between mosquitoes and infected humans. It is possible that vertical transmission is contributing to the number of infected mosquitoes, which are, in turn, capable of transmitting this virus to a higher number of humans. However, the relative importance of vertical transmission for the maintenance and spread of the virus cannot be elucidated with the data available so far.

The MIR is usually affected by the number of mosquitoes that make up the pool of mosquitoes (or their immature stages) tested, which usually causes an underestimation of the real number of infected mosquitoes in a population (10). Thus, the rate of vertical transmission in the mosquito populations from Morelos might be even higher than estimated. Previous studies performed with other flaviviruses, such as DENV, have reported MIRs as low as 0.18 (28) and $0.6(29)$ or as high as 40 (30) in wild larvae, usually associated with the collection date and the place of sampling. Under laboratory conditions, the filial infectious rate of Zika virus in Ae. aegypti mosquitoes ranged from 4.9 to 24.6, depending on the strain of the virus tested (31), which corroborates that our results are comparable to the MIRs reported for other Zika viruses and other flaviviruses, including DENV $(32,33)$.
In this work, we were also able to demonstrate the natural vertical transmission of Zika virus in Ae. aegypti mosquitoes by the successful isolation of infectious Zika virus (31N) from larvae raised from field-collected eggs. This evidence strongly suggests that infectious Zika virus can be transmitted from adult female mosquitoes to their offspring and increases the evidence of the role of natural vertical transmission in the maintenance of Zika virus in wild mosquito populations.

The isolation of infective Zika virus vertically transmitted from adult mosquitoes to their offspring suggests that this virus could be potentially transmissible between mosquitoes and their vertebrate hosts; nevertheless, this transmission still needs to be demonstrated. Moreover, we were able to detect several SNVs in the larvae-derived Zika virus isolate $31 \mathrm{~N}$, of which 3 were specific to this larvaederived genome, as well as 10 others that were shared between the larvae and other mosquito and human sequences. Although it is plausible that these SNVs were acquired during virus culture, we think this is unlikely because 72 of the sequences included in the alignment corresponded to cultured viruses and none of them presented these mutations; however, the sequences from more larvae-derived viruses need to be determined to establish the significance of these SNVs. The larvae-specific SNVs were located in the coding regions for the NS2A and NS3 proteins, which are involved in the replication of the viral RNA (34). Nevertheless, whether the larvae-specific SNVs are associated with the maintenance and vertical transmission of infectious Zika virus from adult mosquitoes to their offspring still needs to be determined. 


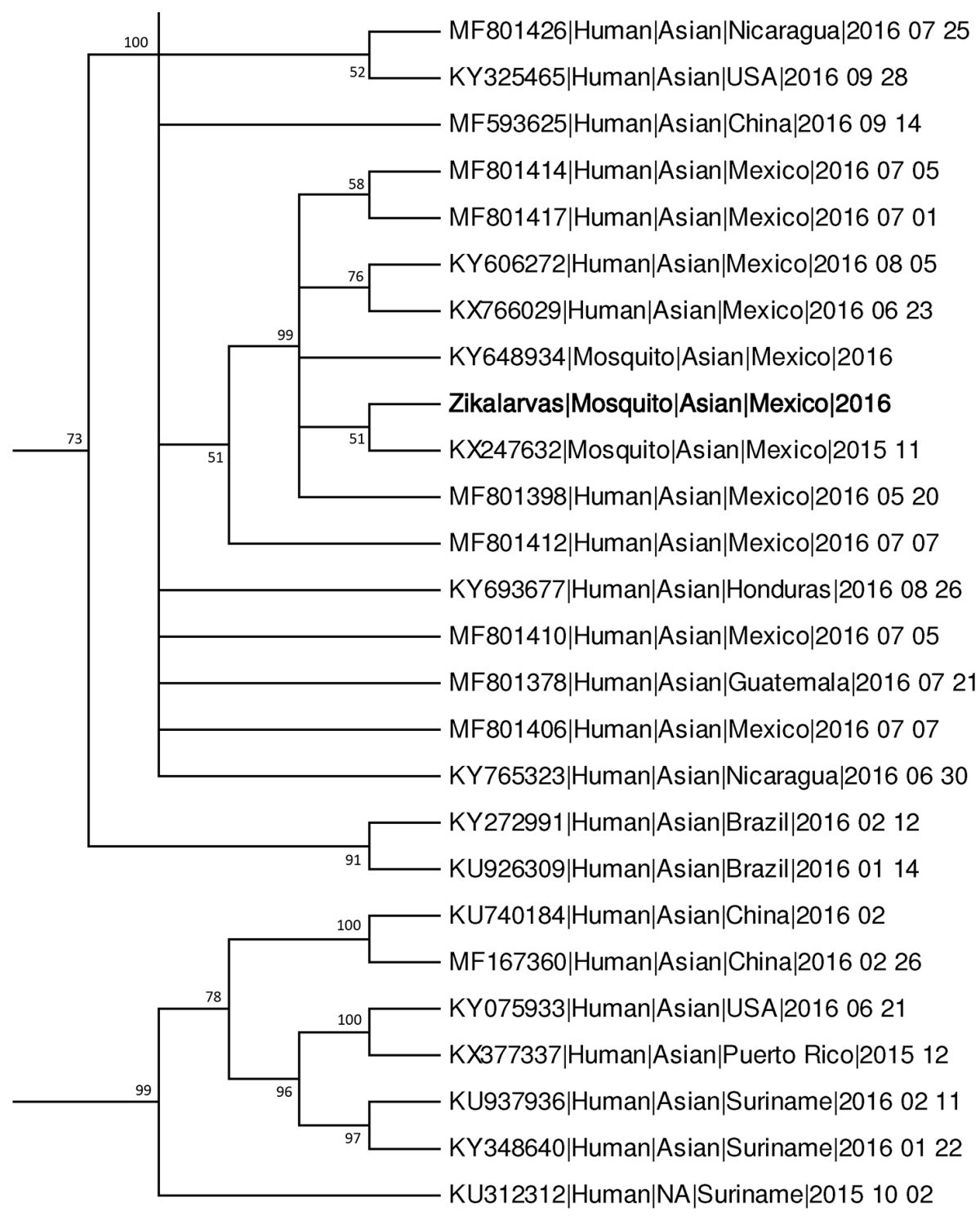

Figure 3. Condensed phylogenetic reconstruction of selected complete Zika virus genomes. This selection from the tree depicts the phylogenetic relationships between Zika virus isolate $31 \mathrm{~N}$ from an Aedes aegypti larval pool, Jojutla, Morelos, Mexico (bold), and 98 complete genome sequences of Zika viruses obtained from the Virus Pathogen Resource database. GenBank accession numbers are provided. Nodes with bootstrap values support $<50 \%$ were condensed and branch lengths were normalized to emphasize tree topology. The full phylogenetic tree is available online (http://wwwnc.cdc. gov/EID/article/25/8/18-1533-F1.htm).

In summary, we demonstrated natural vertical transmission of Zika virus in wild Ae. aegypti mosquitoes. Our results suggest that this transmission mode could aid in the spread and maintenance of Zika virus in nature, expanding the ongoing zoonotic threat from this virus to human health.

\section{Acknowledgments}

We thank Jorge Luis Peralta Rodríguez and Carlos Marx Ramírez Huicochea for their help in the mosquito collection and identification and Vadim Pérez Koldenkova for his support with the confocal microscopy at the Laboratorio Nacional de Microscopia Avanzada/Centro Medico Nacional Siglo XXI, IMSS.

This work was supported by grants CONACyT 183448 , CONACyT 233977, and CONACyT 269826.

\section{About the Author}

Ms. Izquierdo-Suzán is a graduate student at Universidad Autónoma de la Ciudad de México, Mexico City, Mexico. Her primary research interests are molecular and ecological aspects of emerging infectious diseases in wildlife.

\section{References}

1. Hasan SS, Sevvana M, Kuhn RJ, Rossmann MG. Structural biology of Zika virus and other flaviviruses. Nat Struct Mol Biol. 2018;25:13-20. http://dx.doi.org/10.1038/s41594-017-0010-8

2. Russo FB, Jungmann P, Beltrão-Braga PCB. Zika infection and the development of neurological defects. Cell Microbiol. 2017;19:e12744. http://dx.doi.org/10.1111/cmi.12744

3. Main BJ, Nicholson J, Winokur OC, Steiner C, Riemersma KK, Stuart J, et al. Vector competence of Aedes aegypti, Culex tarsalis, and Culex quinquefasciatus from California for Zika virus. PLoS Negl Trop Dis. 2018;12:e0006524. http://dx.doi.org/10.1371/ journal.pntd.0006524 
4. Saiz JC, Vázquez-Calvo Á, Blázquez AB, Merino-Ramos T, Escribano-Romero E, Martín-Acebes MA. Zika virus: the latest newcomer. Front Microbiol. 2016;7:496. http://dx.doi.org/10.3389/ fmicb.2016.00496

5. Vorou R. Zika virus, vectors, reservoirs, amplifying hosts, and their potential to spread worldwide: what we know and what we should investigate urgently. Int J Infect Dis. 2016;48:85-90. http://dx.doi.org/10.1016/j.ijid.2016.05.014

6. Tilak R, Ray S, Tilak VW, Mukherji S. Dengue, chikungunya ... and the missing entity -Zika fever: a new emerging threat. Med J Armed Forces India. 2016;72:157-63. http://dx.doi.org/10.1016/ j.mjafi.2016.02.017.

7. Kraemer MU, Sinka ME, Duda KA, Mylne A, Shearer FM, Brady OJ, et al. The global compendium of Aedes aegypti and Ae. albopictus occurrence. Sci Data. 2015;2:150035. http://dx.doi.org/ 10.1038/sdata.2015.35

8. da Costa CF, Dos Passos RA, Lima JBP, Roque RA, de Souza Sampaio V, Campolina TB, et al. Transovarial transmission of DENV in Aedes aegypti in the Amazon basin: a local model of xenomonitoring. Parasit Vectors. 2017;10:249. http://dx.doi.org/10.1186/s13071-017-2194-5

9. Adams B, Boots M. How important is vertical transmission in mosquitoes for the persistence of dengue? Insights from a mathematical model. Epidemics. 2010;2:1-10. http://dx.doi.org/ 10.1016/j.epidem.2010.01.001

10. Grunnill M, Boots M. How important is vertical transmission of dengue viruses by mosquitoes (Diptera: Culicidae)? J Med Entomol. 2016;53:1-19. http://dx.doi.org/10.1093/jme/tjv168

11. Lequime S, Fontaine A, Ar Gouilh M, Moltini-Conclois I, Lambrechts L. Genetic drift, purifying selection and vector genotype shape dengue virus intra-host genetic diversity in mosquitoes. PLoS Genet. 2016;12:e1006111. http://dx.doi. org/10.1371/journal.pgen.1006111

12. Li CX, Guo XX, Deng YQ, Xing D, Sun AJ, Liu QM, et al. Vector competence and transovarial transmission of two Aedes aegypti strains to Zika virus. Emerg Microbes Infect. 2017;6:1-7. http://dx.doi.org/10.1038/emi.2017.8

13. Thangamani S, Huang J, Hart CE, Guzman H, Tesh RB. Vertical transmission of Zika virus in Aedes aegypti mosquitoes. Am J Trop Med Hyg. 2016;95:1169-73. http://dx.doi.org/10.4269/ajtmh.16-0448

14. Dirección General de Epidemiologia SS. Boletín Epidemiológico. Sistema Nacional de Vigilancia Epidemiológica. Contract no. semana 52. 2016 [cited 2018 Sep 21]. https://www.gob.mx/cms/ uploads/attachment/file/179535/sem52.pdf

15. Lanciotti RS, Kosoy OL, Laven JJ, Velez JO, Lambert AJ, Johnson AJ, et al. Genetic and serologic properties of Zika virus associated with an epidemic, Yap State, Micronesia, 2007. Emerg Infect Dis. 2008;14:1232-9. http://dx.doi.org/10.3201/eid1408.080287

16. Grabherr MG, Haas BJ, Yassour M, Levin JZ, Thompson DA, Amit I, et al. Full-length transcriptome assembly from RNA-Seq data without a reference genome. Nat Biotechnol. 2011;29:644-52. http://dx.doi.org/10.1038/nbt.1883

17. García-Alcalde F, Okonechnikov K, Carbonell J, Cruz LM, Götz S, Tarazona S, et al. Qualimap: evaluating next-generation sequencing alignment data. Bioinformatics. 2012;28:2678-9. http://dx.doi.org/10.1093/bioinformatics/bts503

18. Pickett BE, Greer DS, Zhang Y, Stewart L, Zhou L, Sun G, et al. Virus pathogen database and analysis resource (ViPR): a comprehensive bioinformatics database and analysis resource for the coronavirus research community. Viruses. 2012;4:3209-26. http://dx.doi.org/10.3390/v4113209

19. Guindon S, Gascuel O. A simple, fast, and accurate algorithm to estimate large phylogenies by maximum likelihood. Syst Biol. 2003;52:696-704. http://dx.doi.org/10.1080/10635150390235520

20. Anisimova M, Gascuel O. Approximate likelihood-ratio test for branches: A fast, accurate, and powerful alternative.
Syst Biol. 2006;55:539-52. http://dx.doi.org/10.1080/10635150 600755453

21. Pickett BE, Liu M, Sadat EL, Squires RB, Noronha JM, He S, et al. Metadata-driven comparative analysis tool for sequences (meta-CATS): an automated process for identifying significant sequence variations that correlate with virus attributes. Virology. 2013;447:45-51. http://dx.doi.org/10.1016/j.virol.2013.08.021

22. Coffey LL, Page BL, Greninger AL, Herring BL, Russell RC, Doggett SL, et al. Enhanced arbovirus surveillance with deep sequencing: identification of novel rhabdoviruses and bunyaviruses in Australian mosquitoes. Virology. 2014;448:146-58. http://dx.doi.org/10.1016/j.virol.2013.09.026

23. Ibáñez-Bernal S, Briseño B, Mutebi JP, Argot E, Rodríguez G, Martínez-Campos C, et al. First record in America of Aedes albopictus naturally infected with dengue virus during the 1995 outbreak at Reynosa, Mexico. Med Vet Entomol. 1997;11:305-9. http://dx.doi.org/10.1111/j.1365-2915.1997.tb00413.x

24. Günther J, Ramírez-Palacio LR, Pérez-Ishiwara DG, Salas-Benito JS. Distribution of dengue cases in the state of Oaxaca, Mexico, during the period 2004-2006. J Clin Virol. 2009;45:218-22. http://dx.doi.org/ 10.1016/j.jcv.2009.05.007

25. Martínez NE, Dzul-Manzanilla F, Gutiérrez-Castro C, Ibarra-López J, Bibiano-Marín W, López-Damián L, et al. Natural vertical transmission of dengue-1 virus in Aedes aegypti populations in Acapulco, Mexico. J Am Mosq Control Assoc. 2014;30:143-6. http://dx.doi.org/10.2987/14-6402.1

26. Ferreira-de-Brito A, Ribeiro IP, Miranda RM, Fernandes RS, Campos SS, Silva KA, et al. First detection of natural infection of Aedes aegypti with Zika virus in Brazil and throughout South America. Mem Inst Oswaldo Cruz. 2016;111:655-8. http://dx.doi.org/10.1590/0074-02760160332

27. Smartt CT, Shin D, Alto BW. Dengue serotype-specific immune response in Aedes aegypti and Aedes albopictus. Mem Inst Oswaldo Cruz. 2017;112:829-37. http://dx.doi.org/10.1590/0074-02760170182

28. Vilela AP, Figueiredo LB, dos Santos JR, Eiras AE, Bonjardim CA, Ferreira PC, et al. Dengue virus 3 genotype I in Aedes aegypti mosquitoes and eggs, Brazil, 2005-2006. Emerg Infect Dis. 2010;16:989-92. http://dx.doi.org/10.3201/eid1606.091000

29. Guedes DR, Cordeiro MT, Melo-Santos MA, Magalhaes T, Marques E, Regis L, et al. Patient-based dengue virus surveillance in Aedes aegypti from Recife, Brazil. J Vector Borne Dis. 2010;47:67-75.

30. Lee HL, Rohani A. Transovarial transmission of dengue virus in Aedes aegypti and Aedes albopictus in relation to dengue outbreak in an urban area in Malaysia. New Delhi: WHO Regional Office for South-East Asia; 2005. p. 106-11.

31. Ciota AT, Bialosuknia SM, Zink SD, Brecher M, Ehrbar DJ, Morrissette MN, et al. Effects of Zika virus strain and Aedes mosquito species on vector competence. Emerg Infect Dis. 2017;23:1110-7. http://dx.doi.org/10.3201/eid2307.161633

32. Edillo FE, Sarcos JR, Sayson SL. Natural vertical transmission of dengue viruses in Aedes aegypti in selected sites in Cebu City, Philippines. J Vector Ecol. 2015;40:282-91. http://dx.doi.org/ 10.1111/jvec.12166

33. Apodaca-Medina AI, Torres-Avendaño JI, Rendón-Maldonado JG, Torres-Montoya EH, Flores-López BA, Del Angel RM, et al. First evidence of vertical infection of dengue virus 2 in Aedes aegypti mosquitoes from Sinaloa, Mexico. Vector Borne Zoonotic Dis. 2018;18:231-3. http://dx.doi.org/10.1089/vbz.2017.2202

34. Barrows NJ, Campos RK, Liao KC, Prasanth KR, Soto-Acosta R, Yeh SC, et al. Biochemistry and molecular biology of flaviviruses. Chem Rev. 2018;118:4448-82. http://dx.doi.org/10.1021/acs. chemrev.7b00719

Address for correspondence: Martha Yocupicio-Monroy, Universidad Autónoma de la Ciudad de México, Posgrado en Ciencias Genómicas, San Lorenzo \#290 Col Del Valle, CP 03100, Mexico City, Mexico; email: martha.ym1@gmail.com 